\title{
Synthesis, Characterization and Antibacterial Activity Evaluation of 4-amino Antipyrine Derivatives and Their Transition Metal Complexes
}

\author{
Salah Hamza Sherif*, Dagne Addisu Kure, Endalkachew Asefa Moges, Bekele Argaw \\ Department of Chemistry, Hawassa University, Hawassa, Ethiopia \\ Email address: \\ hamzasalahsherif@gmail.com (S. H. Sherif) \\ ${ }^{*}$ Corresponding author \\ To cite this article: \\ Salah Hamza Sherif, Dagne Addisu Kure, Endalkachew Asefa Moges, Bekele Argaw. Synthesis, Characterization and Antibacterial Activity \\ Evaluation of 4-amino Antipyrine Derivatives and Their Transition Metal Complexes. American Journal of Bioscience and Bioengineering. \\ Vol. 9, No. 1, 2021, pp. 8-12. doi: 10.11648/j.bio.20210901.12
}

Received: December 26, 2020; Accepted: January 11, 2021; Published: February 23, 2021

\begin{abstract}
Due to their importance as catalysts in many reactions and their biological activities, an interest in the synthesis and characterization of transition metal complexes containing Schiff bases is increasing. Schiff base ligands have achieved considerable attention by the scientist over the decades as potential drug agent, Azomethine linkage $(-\mathrm{CH}=\mathrm{N}-)$ of Schiff base play a significant role in medical chemistry. Derivatives of Schiff bases of 4-aminoantipyrine viz, 4-(2-hydroxy-3-methoxy benzylid ene amino)-1,2-dihydro-2,3-dimethyl-1-phenylpyrazol-5-one (4) and 4-((5-methylfuran-2-yl) methylene amino)-1,2dihydro-2,3-dimethyl-1-phenylpyrazol-5-one (5) and their Co (II), Ni (II), Cu (II) complexes were successfully synthesized, the Schiff bases ligand (4) and (5) were synthesized by condensation reaction. The structures of all the synthesized ligands were confirmed by using IR, UV-Visible, ${ }^{1} \mathrm{H}$ NMR, and ${ }^{13} \mathrm{C}$ NMR. The $\mathrm{Cu}$ (II), Ni (II) and Co (II) complexes were confirmed by using IR and VU-Visible. The complexes are electrolytic in nature as indicated by molar conductance measurements. The data have shown that all complexes possess octahedral geometry. In-vitro antibacterial activity of all the synthesized ligands and their metal complexes were carried out by using disc diffusion method against Staphylococcus aureus, Escherichia coli and Pseudomonas aeruginosa bacterial strain. Compound Co (4) has exhibited better antibacterial activity than the standard drug against $\mathrm{S}$. aureus ( $25 \mathrm{~mm}$ zone of inhibition compared to the standard antibiotic Oxacillin ( $23 \mathrm{~mm}$ zone of inhibition).
\end{abstract}

Keywords: Schiff Base, 4-aminoantipyrine, Ortho-vanillin, 5-methyl Furfural, Transition Metal Complexes, Antimicrobial

\section{Introduction}

Heterocyclic compounds are important class of organic compounds due to their chemical, biological, and technical significance, [1] these compounds are widely distributed in nature and essential to many biochemical processes [2].

Antipyrine (1,5-dimethyl-2-phenylpyrazole-3-one) is a compound that possesses a pyrazolone moiety with a fivemembered lactam ring containing two nitrogens and a ketone in the same molecule $[3,4]$. Antipyrine and its 4amino derivative (4-amino-1,5-dimethyl-2phenylpyrazole-3-one) forms a variety of Schiff bases with aldehydes, and a remarkable number of compounds have recently been reported $[5,6]$. 4-Aminoantipyrine and its derivatives have been synthesized and investigated for its biological activities such as anti-inflammatory [7, 8], antibacterial, $[9,10]$ anthelmintic [11], anticancer [12, 13] etc. activities

Schiff base compounds containing an azomethine group ($\mathrm{CH}=\mathrm{N}-$ ) have received considerable attention in the field of chemistry and biology due to their chemotherapeutic value. $[14,15]$ Biological activity evaluation of transition metal complexes derived from Schiff base ligands were widely investigated and have attracted more attention by various researchers, schiff base ligands can coordinate to metal ions via azomethine nitrogen and have been studied extensively. In azomethine derivatives, the $\mathrm{C}=\mathrm{N}$ linkage is essential for biological activity, several azomethine have been reported to possess remarkable antibacterial, antifungal, anticancer and antimalarial activities [16] 
In this paper, we present the synthesis and anti bacterial activity investigations of Schiff bases of antipyrine and their metal complex against Escherichia. coli, Pseudomonas aeruginosa and Staphylococcus aureus bacterial strain. The major aim of this study was to compare the activity of the ligands with their metal complexes.

\section{Result and Discussion}

\subsection{Antibacterial Activities}

The antibacterial activity was determined with the disc diffusion method. The in vitro antibacterial screening was done against the bacterial species Escherichia. coli, Pseudomonas aeruginosa and Staphylococcus aureus. The bacterial cultures were inoculated in nutrient broth (inoculation medium) and incubated overnight at $37^{\circ} \mathrm{C}$. Inoculated medium containing $24 \mathrm{~h}$ grown culture was added aseptically to the nutrient medium and mixed thoroughly to get a uniform distribution. This solution was poured into Petri dishes and then allowed to attain room temperature. Wells (6 $\mathrm{mm}$ in diameter) were punched carefully using a sterile cork borer and were filled with test solution 10 $\mathrm{mg} / \mathrm{mL}$. The plate was allowed to stand for an hour in order to facilitate the diffusion of the drug solutions, then the plates were incubated at $37^{\circ} \mathrm{C}$ for $24 \mathrm{~h}$ for bacteria and the diameter of the zone of inhibition were measured

The synthesized Schiff bases and their Co (II), Ni (II), and Cu (II) complexes were tested in-vitro antibacterial activity against Escherichia coli, Staphylococcus aureus, and Pseudomonas aeruginosa by disc diffusion method. Oxacillin, tobramycin, and Cefotaxime were used as standard antibiotics drug. The zone of inhibition values indicates that all the compounds exhibited a varied range 6-25 $\mathrm{mm}$ of antibacterial activity (table 1) against all the tested bacterial strains.

Table 1. In-vitro antibacterial activity values of the synthesized ligands $(4,5)$ and their $\mathrm{Cu}(\mathrm{II}), \mathrm{Ni}(\mathrm{II})$ and $\mathrm{Co}(\mathrm{II})$ complexes.

\begin{tabular}{llll}
\hline \multicolumn{3}{c}{ Antibacterial activity (inhibition zone diameter in mm) } \\
\hline \multirow{2}{*}{ Compound } & Bacterial strain & \multicolumn{2}{l}{} \\
\cline { 2 - 4 } & $\begin{array}{l}\text { Staphylococcus } \\
\text { aureus }\end{array}$ & $\begin{array}{l}\text { Escherichia } \\
\text { coli }\end{array}$ & $\begin{array}{l}\text { Pseudomonas } \\
\text { aeruginosa }\end{array}$ \\
\hline 4 & 6 & 6 & 6 \\
$\mathrm{Co}(4)$ & 25 & 22 & 14 \\
$\mathrm{Ni}(4)$ & 14 & 13 & 6 \\
$\mathrm{Cu}(4)$ & 19 & 12 & 6 \\
5 & 6 & 6 & 6 \\
$\mathrm{Ni}(5)$ & 18 & 19 & 20 \\
$\mathrm{Cu}(5)$ & 15 & 14 & 6 \\
Oxacillin & 23 & 32 & \\
Cefotaxime & & 3 & \\
Tobramycin & & & 21 \\
\hline
\end{tabular}

Note: The size of $6 \mathrm{~mm}$ means that no activity (there was no zone of inhibition)

\subsection{Molar Conductivity of the Metal Complexes}

The molar conductance for the complexes measured in $10^{-3}$ $\mathrm{M}$ solution in dichloromethane as solvents at room temperature. The result, as shown in the table 2, demonstrated that the complexes have a binuclear nature.
Table 2. Molar conductance data of the complexes.

\begin{tabular}{lll}
\hline Compound & $\boldsymbol{\Lambda}\left(\mathbf{\Omega}^{-\mathbf{1}} \mathbf{c m}^{\mathbf{2}} \mathbf{m o l}^{-\mathbf{1}}\right)$ & Nature \\
\hline $\mathrm{Cu}$ complex of (4) & 182 & Electrolyte \\
Ni complex of (4) & 68 & Electrolyte \\
Co complex of (4) & 56 & Electrolyte \\
Cu complex of (5) & 106 & Electrolyte \\
Ni complex of (5) & 62 & Electrolyte \\
\hline
\end{tabular}

\section{Experimental Section}

\subsection{Materials and Methods}

All chemicals and solvents were purchased from SigmaAldrich and used without further purification; the reaction process was monitored by TLC silica gel plates; the purification of the products was performed using column chromatography using silica gel (100- 200mesh). The melting point was determined in a capillary tube using an electro thermal points apparatus and thermometer; Infrared spectra were recorded on Perkin-Elmer FT-IR model spectrophotometer in the range of $4000-400 \mathrm{~cm}^{-1}$ with a $\mathrm{KBr}$ pellet as a reference material; Electronic spectra were measured in Lambda 950 UV/VIS/NIR spectrometer in the range $200-800 \mathrm{~nm}$ at room temperature. ${ }^{1} \mathrm{H}$ and ${ }^{13} \mathrm{C}$ NMR were recorded using Bruker Avance NMR spectrometer $(400 \mathrm{MHz})$ using DMSO- $d 6$ and $\mathrm{CDCl}_{3}$ as solvent and tetramethyl silane (TMS) as an internal standard. Molar conductivities were recorded at room temperature using electrical conductivity meter. The antibacterial activity was determined with the Disc Diffusion method.

\subsection{Chemistry}

The titled compounds and their metal complexes described in this study were synthesized as outlined in figure 1 , the Schiff base ligands were synthesized by the condensation of 4-aminoantipyrine with appropriate aldehyde in ethanol in the presence of acetic acid as a catalyst, the metal complexes of the ligands were prepared by refluxing the ligands with appropriate metal salt in ethanol.

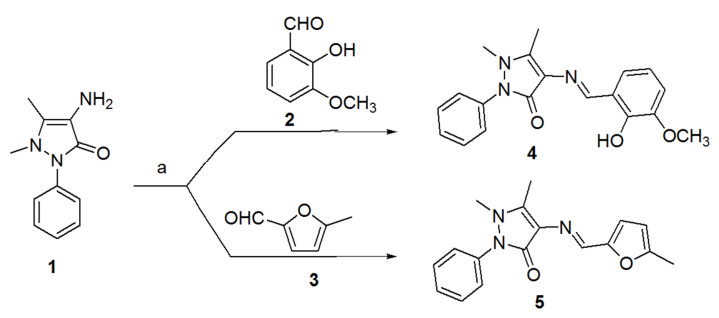

Figure 1. Synthesis of ligands (4) and (5): Reagent and condition: a) EtOH, AcOH, reflux.

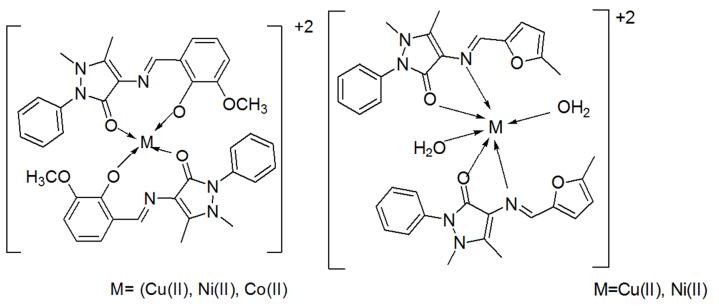

Figure 2. Proposed structure of the metal complexes. 


\subsection{Synthesis and Characterization of Ligands}

\subsubsection{General Procedure for the Synthesis of Schiff Bases (4) and (5)}

A mixture of 4-aminoantipyrine (1) $(0.5081 \mathrm{~g}, 0.5 \mathrm{mmol})$ and appropriate aldehyde ( 2 or 3$)(0.5 \mathrm{mmol})$ were dissolved in $20 \mathrm{~mL}$ of ethanol, 3-5drops of glacial acetic acid was added as a catalyst. The reaction mixtures were refluxed at a temperature of $80^{\circ} \mathrm{C}$ for 6 hours. The progress of the reaction was monitored by TLC. After completion of the reaction, the resulting mixtures were cooled to room temperature and the obtained precipitates were filtered, washed several times with ethanol and dried over anhydrous calcium chloride under vacuum. Then the crude residue was further purified by column chromatography (Silica gel 200-400 mesh) using hexane: ethyl acetate as eluents affording the ligands (4 or 5 )

\subsubsection{Characterization of Schiff Bases of (4) and (5)}

i. 4-(2-hydroxy-3-methoxybenzylideneamino)-1,2dihydro-2,3-dimethyl-1-phenylpyrazol-5-one (4)

Yellow crystal; Yield: $86 \%$; Mp: $178-180^{\circ} \mathrm{C}$; $\mathrm{IR}(\mathrm{KBr}$, $\mathrm{Cm}-1): \quad 3454(\mathrm{OH}, \quad$ phenolic $), \quad 1665(\mathrm{C}=\mathrm{O}, \quad$ carbonyl $)$, 1602(C=N, azomethine); ${ }^{1} \mathrm{HNMR}\left(\mathrm{CDCl}_{3}, 400 \mathrm{MHz}\right): \delta 13.9(\mathrm{~s}$, $1 \mathrm{H}, \mathrm{OH}), 9.81(\mathrm{~s}, 1 \mathrm{H}, \mathrm{HC}=\mathrm{N}), 6.82-7.46(\mathrm{~m}, 8 \mathrm{H}, \mathrm{Ar}-\mathrm{H}), 3.86(\mathrm{~s}$, $3 \mathrm{H}), 3.1(\mathrm{~s}, 3 \mathrm{H}), 2.37(\mathrm{~s}, 3 \mathrm{H}) ;{ }^{13} \mathrm{C} \mathrm{NMR}\left(\mathrm{CDCl}_{3}, 100 \mathrm{MHz}\right): \delta$ $160.2,150.3,149.8,148.0,134.2,129.3,127.2,124.6,123.5$, $120.1,118.5,115.8,113.5,110.1,56.0,35.5,10.0$

ii. 4-((5-methylfuran-2-yl) methylene amino)-1,2dihydro-2,3-dimethyl-1-phenylpyrazol-5-one (5)

Orange crystal; Yield: $80 \%$; Mp: $179-180^{\circ} \mathrm{C}$; $\mathrm{IR}(\mathrm{KBr}$, $\mathrm{Cm}-1): 1638(\mathrm{C}=\mathrm{O}$, carbonyl $), 1574(\mathrm{C}=\mathrm{N}$, azomethine $)$, 1492(HC=N); HNMR(DMSO- $\left.d_{6}, 400 \mathrm{MHz}\right): \delta 9.80(\mathrm{~s}, 1 \mathrm{H}$, $\mathrm{HC}=\mathrm{N}), 7.36-7.52(\mathrm{~m}, 5 \mathrm{H}, \mathrm{Ar}-\mathrm{H}), 6.84(\mathrm{~d}, J=0.4 \mathrm{~Hz}$, furan proton), 6.26 (d, $J=0.4$, furan proton), $3.43(\mathrm{~s}, 3 \mathrm{H}), 2.38(\mathrm{~s}$, $3 \mathrm{H}$ ); ${ }^{13} \mathrm{C}$ NMR (DMSO- $\left.d_{6}, 100 \mathrm{MHz}\right), \delta 160.1,155.2,152.0$, $151.9,143.7,134.9,129.6,127.3,124.9,117.0,116.2,109.2$, $35.8,14.3,10.3$

\subsection{Synthesis and Characterization of Metal Complexes of} (4)

\subsubsection{Procedure for the Synthesis of $\mathrm{Cu}(\mathrm{II}), \mathrm{Ni}(\mathrm{II})$, and Co(II) Complexes of (4)}

An ethanolic solution (10 ml) of (4) $(0.337 \mathrm{gm}, 0.5 \mathrm{mmol})$ was added drop wise to $5 \mathrm{ml}$ hot methanol solution of $\mathrm{Cu}$ $\left(\mathrm{CH}_{3} \mathrm{COO}\right)_{2} \cdot \mathrm{H}_{2} \mathrm{O}$, Ni $\left(\mathrm{CH}_{3} \mathrm{COO}\right)_{2} \cdot \mathrm{H}_{2} \mathrm{O}$, or $\mathrm{CoCl}_{2} \cdot 6 \mathrm{H}_{2} \mathrm{O}$ $(0.5 \mathrm{mmol})$. The reaction mixture was refluxed at temperature of $70-80^{\circ} \mathrm{C}$ for $7-8$ hours. The completion of the reaction was monitored by disappearance of spot on TLC plates using nhexane: ethyl acetate (7:3) as mobile phase, the product obtained was filtered, washed thoroughly with ethanol. The sample was recrystallized using dichloromethane

\subsubsection{Characterization of Metal Complexes of (4)}

i. Characterization of Copper (II) complexes of (4)

Fine Blue Black powder; Yield: $67 \%$; $\mathrm{Mp}: 167-170^{\circ} \mathrm{C}$; $\mathrm{IR}(\mathrm{KBr}, \mathrm{Cm}-1): 1610(\mathrm{C}=\mathrm{N}$, azomethine $), 1657(\mathrm{C}=\mathrm{O}$, carbonyl). The imine bond $\mathrm{C}=\mathrm{N}$ stretching shifted to higher value in the spectra of the complexes indicating the coordination of azomethine nitrogen to the metal ions. The bands in the low frequency region 735 and 522 is due to the formation of $v(\mathrm{M}-\mathrm{O})$ and $v(\mathrm{M}-\mathrm{N})$ vibrations respectively.

Electronic spectrum of $\mathrm{Cu}$ complexes of (4)

The UV/visible electronic absorption spectra of the Schiff base ligand and its metal complexes were recorded in $\mathrm{CDCl}_{3}$ at room temperature.

The spectrum of $\mathrm{Cu}$ (II) complex of ligand (4) shows three bands at 334,358 , and $430 \mathrm{~nm}$. The two absorption band at $334 \mathrm{~nm}$ and $358 \mathrm{~nm}$ assigned to $\pi \rightarrow \pi^{*}$ and $\mathrm{n} \rightarrow \pi^{*}$ transition respectively and band at $430 \mathrm{~nm}$ assigned to charge transfer

ii. Characterization of $\mathrm{Ni}$ (II) complexes of (4)

Light green fine powder; Yield $72 \%$; $\mathrm{Mp}: 140-142^{\circ} \mathrm{C}$; $\mathrm{IR}\left(\mathrm{KBr}, \mathrm{Cm}^{-1}\right): 3418(\mathrm{O}-\mathrm{H})$ suggests that the coordinated water molecule is present in the $\mathrm{Ni}$ (II) complex, $1657(\mathrm{C}=\mathrm{O})$, $1583(\mathrm{C}=\mathrm{N}$, azomethine $), 1456(\mathrm{CH}=\mathrm{N})$, the bands in the low frequency region 726 and 561 is due to the formation of $v(\mathrm{M}-\mathrm{O})$ and $v(\mathrm{M}-\mathrm{N})$ vibrations respectively.

Electronic spectrum of $\mathrm{Ni}$ (II) complexes of (4)

The spectrum of Ni (II) complex shows three bands at 320, 334 , and $366 \mathrm{~nm}$. The bands at 320 and $334 \mathrm{~nm}$ assigned to carbonyl $\pi \rightarrow \pi^{*}$ and azomethine $\mathrm{n} \rightarrow \pi^{*}$ transition respectively, and the bands at $366 \mathrm{~nm}$ could be assigned for corresponding charge transfer, which justified the octahedral geometry of Ni complex

iii. Characterization of Co (II) complexes of (4)

Deep green Fine powder; Yield: $76.6 \%$; Mp: $188-192^{\circ} \mathrm{C}$; $\mathrm{IR}\left(\mathrm{KBr}, \quad \mathrm{Cm}^{-1}\right): \quad 1661(\mathrm{C}=\mathrm{O}, \quad$ carbonyl $), \quad 1600 \quad(\mathrm{C}=\mathrm{N}$, azomethine), $1467(\mathrm{HC}=\mathrm{N})$, the bands in the low frequency region 565 and 467 is due to the formation of (M-O) and $(\mathrm{M}-\mathrm{N})$ vibrations respectively

Electronic spectrum of Co(II) complexes of (4)

The electronic absorption spectral bands of Co (II) complex in chloroform are observed in the three main UV regions: 323,335 , and $370 \mathrm{~nm}$. The electronic spectrum of Co (II) complex absorption bands at $323 \mathrm{~nm}$ is due to $\pi \rightarrow \pi^{*}$ transition of the carbonyl group $(\mathrm{C}=\mathrm{O})$. The band at $335 \mathrm{~nm}$ can be attributed to the $\mathrm{n} \rightarrow \pi^{*}$ of the $(\mathrm{HC}=\mathrm{N})$ transitions. The peak at $370 \mathrm{~nm}$ is due to charge transfer.

\subsection{Synthesis and Characterization of Metal Complexes of} (5)

\subsubsection{General Procedure for the Synthesis of $\mathrm{Cu}(\mathrm{II}), \mathrm{Ni}(\mathrm{II})$, Co(II) Complexes of (5)}

An ethanolic solution $(10 \mathrm{ml})$ of (5) $(0.2953 \mathrm{gm}, 0.5 \mathrm{mmol})$ was added drop wise to $5 \mathrm{ml}$ solution of $(0.5 \mathrm{mmol})$ of the $\mathrm{Cu}$ $\left(\mathrm{CH}_{3} \mathrm{COO}\right)_{2} \cdot \mathrm{H}_{2} \mathrm{O}$, Ni $\left(\mathrm{CH}_{3} \mathrm{COO}\right)_{2} \cdot \mathrm{H}_{2} \mathrm{O}$ in methanol with constant stirring. The reaction mixture was refluxed at temperature of $80^{\circ} \mathrm{C}$, for 12 hours. The completion of the reaction was monitored by disappearance of spot on TLC plates using n-hexane: ethyl acetate $(8: 2)$ as mobile phase. The product obtained was filtered off, washed thoroughly with ethanol. The sample was recrystallized using dichloromethane

\subsubsection{Characterization of Metal Complexes of (5)}

i. Characterization of Copper (II) complexes of (5) 
Black sticky powder, Yield: $84.5 \%$; Mp: $199-201^{\circ} \mathrm{C}$; IR $\left(\mathrm{KBr}, \mathrm{Cm}^{-1}\right): \quad 3418(\mathrm{OH}$, water molecules $), \quad 1657(\mathrm{C}=\mathrm{O}$, carbonyl), $1602(\mathrm{C}=\mathrm{N}$, azomethine $), 1483(\mathrm{CH}=\mathrm{N})$, the new bands in the low frequency region 735 and 552, is due to the formation of $(\mathrm{M}-\mathrm{O})$ and $(\mathrm{M}-\mathrm{N})$ vibrations respectively.

Electronic spectrum of Cu(II) complexes of (5)

The electronic absorption bands showed at 280, 296, and $343 \mathrm{~nm}$, the bands at $296 \mathrm{~nm}$ is attributed to $\mathrm{n} \rightarrow \pi^{*}$ transition of $\mathrm{C}=\mathrm{O}$ groups and the band at $280 \mathrm{~nm}$ can be attributed to the

$\pi \rightarrow \pi^{*}$ transition of the $\mathrm{HC}=\mathrm{N}$ functional group. The appearance of new bands at $343 \mathrm{~nm}$ is due to charge transfer

ii. Characterization of $\mathrm{Ni}$ (II) complexes of (5)

Light Brown Needle like Crystal, Yield: 70\%; Mp: $135-$ $138^{\circ} \mathrm{C}$; $\mathrm{IR}\left(\mathrm{KBr}, \mathrm{Cm}^{-1}\right): 3427(\mathrm{OH}$ of water $), 1657(\mathrm{C}=\mathrm{O}$, carbonyl), $1565(\mathrm{C}=\mathrm{N}$, azomethine $), 1410(\mathrm{HC}=\mathrm{N})$, new bands in the region of 680 and 452 is due to metal ligand (M-N) and (M-O) vibration respectively.

Electronic spectrum of $\mathrm{Ni}(\mathrm{II})$ complexes of (5)

The spectrum of Ni (II) Schiff base complex shows three bands at 248, 344, and 356, the band at $248 \mathrm{~nm}$ is due to $\pi \rightarrow$ $\pi^{*}$ transition of the carbonyl group $(\mathrm{C}=\mathrm{O})$ and the band at 344 $\mathrm{nm}$ can be attributed to the $\mathrm{n} \rightarrow \pi^{*}$ of the $(\mathrm{HC}=\mathrm{N})$ transitions, and the band at $356 \mathrm{~nm}$ assigned to charge transfer.

\section{Conclusion}

The synthesized Schiff base and their metal complex were tested in-vitro antibacterial activity against Escherichia coli, Staphylococcus aureus, and Pseudomonas aeruginosa by disc diffusion method using Oxacillin, tobramycin, and Cefotaxime as standard antibiotics drug compounds (4) and (5) exhibited no activity against E. coli, S. aureus, and P. aeruginosa. The complexes $\mathrm{Cu}(4)$ and $\mathrm{Co}(4)$ showed better activity against $\mathrm{S}$. aureus and complexes of $\mathrm{Ni}(4), \mathrm{Ni}(5)$, and $\mathrm{Cu}(5)$ showed moderat activity. The complexes Co (4) and Ni(5) showed better activity against $\mathrm{E}$. coli but complexes $\mathrm{Ni}(4), \mathrm{Cu}(4)$ and $\mathrm{Cu}(5)$ showed no activity against E. coli. The Complexes Ni (5) showed better activity against Pseudomonas aeruginosa and $\mathrm{Co}(4)$ showed moderate activity against Pseudomonas aeruginosa. But $\mathrm{Ni}(4)$ and $\mathrm{Cu}(4)$ do not showed any activity against Pseudomonas aeruginosa. In general the complexes show better activity than the ligands.

\section{Acknowledgements}

Authors are thankful to Hawassa University for providing research fund, Ethiopian public institute for antibacterial screening and Addis Ababa University for running NMR spectra

\section{References}

[1] R. Neama, N. M. Aljamali, M. Jari (2014) Synthesis, Identification of Heterocyclic Compounds and Study of Biological Activity, Asian J. Research Chem. 7, 7.
[2] N. Raman, S. J. Raja \& A. Sakthivel, (2009) Transition metal complexes with Schiff-base ligands: 4-aminoantipyrine based derivatives-a review, Journal of Coordination Chemistry 62, 691-709.

[3] M. S. Alam, D.-U. Lee, M. L. Bari, (2014) Antibacterial and Cytotoxic Activities of Schiff Base Analogues of 4Aminoantipyrine, J Korean Soc Appl Biol Chem., 57, 613-619

[4] Sarbast Muhammed Ahmed, Kezhal M. Salih, Hiwa Omer Ahmad, Zanko H. Jawhar, Dashti H. Hamad (2019) Synthesis, spectroscopic characterization and antibacterial activity of new series of Schiff base derived from 4-aminoantipyrine and 2-amino benzimidazole. Zanco J. Med. Sci., 23, 206-216.

[5] Kees KL, Fitzgerald JJ, Steiner KE, Mattes JF, Mihan B, Tosi T, Mondoro D, and McCalebr ML (1996) New potent antihyperglycemic agents in $\mathrm{db} / \mathrm{db}$ mice: synthesis and structure-activity relationship studies of (4-substituted benzyl) (trifluoromethyl)pyrazoles and pyrazolones., J Med Chem. 39, 3920-8.

[6] M. S. Alam, M. S. Alam (2012) Synthesis, Molecular Structure and Antioxidant Activity of (E)-4[Benzylideneamino]-1,5-dimethyl-2-phenyl-1H-pyrazol-

$3(2 \mathrm{H})$-one, a Schiff Base Ligand of 4-Aminoantipyrine. J Chem Crystallogr. 42, 93-102

[7] Burdulene, D., Palaima, A., Stumbryavichyute Z., Talaikite Z. (1996) Synthesis and anti-inflammatory activity of 4aminoantipyrine derivatives of succinamides. Pharm. Chem. J. 33,191-193.

[8] Turan-Zitouni G., Sivaci M., Kilic F. S., Erol K. (2001) Synthesis of some triazolyl-antypyrine derivatives and investigation of analgesic activity. Eur. J. Med. Chem. 36, 685-689.

[9] Sayed G. H., Radwan A., Mohamed S. M., Shiba S. A., Khalil M. (1992) Synthesis and reactions of some 6-aryl and 2,6diaryl-4(4 -antipyrinyl)-2,3,4,5-tetrahydropyridazin-3-ones and screening for their antibacterial activities., Chin. J. Chem. $10,475-480$

[10] M. Manjunath, A. D. Kulkarni, G. B. Bagihalli, S. Malladi, S. A. Patil (2017) Bio-important antipyrine derived Schiff bases and their transition metal complexes: Synthesis, spectroscopic characterization, antimicrobial, anthelmintic and DNA cleavage investigation, Journal of Molecular Structure 1127, 314-321.

[11] I. Mohanram and J. Meshram (2014) Synthesis and Biological Activities of 4-Aminoanti pyrine Derivatives Derived from Betti-Type Reaction, Hindawi Publishing Corporation ISRN Organic Chemistry 1-7.

[12] M. M. Ghorab, M. G. El-Gazzar and M. S. Alsaid (2014) Synthesis, Characterization and Anti-Breast Cancer Activity of New 4-Aminoantipyrine-Based Heterocycles, Int. J. Mol. Sci. $15,7539-7553$.

[13] G. H. Elgemeie, M. A. Abu-Zaied, S. A. Loutfy (2017) 4Aminoantipyrine in carbohydrate research: Design, synthesis and anticancer activity of thioglycosides of a novel class of 4aminoanti pyrines and their corresponding pyrazolopyrimidine and pyrazolopyridine thioglycosides, Tetrahedron $73,5853-5861$.

[14] Cukurovali A, Yilmaz I, Ozmen H, and Ahmedzade M. (2002) Cobalt (II), copper (II), nickel (II) and zinc (II) complexes of two novel Schiff base ligands and their antimicrobial activity. Transition Met Chem. 27, 171-6. 
[15] S. G. Nayak, B. Poojary (2019) Synthesis of novel Schiff bases containing arylpyrimidines as promising antibacterial agents, Heliyon 5, 1-7.
[16] E. Yousif, A. Majeed, K. Al-Sammarrae, N. Salih, J. Salimon, B. Abdullah (2017) Metal complexes of Schiff base: Preparation, characterization and antibacterial activity, Arabian journal of chemistry 10, 1639-1644. 